\title{
Application of Salicylic Acid Derivatives to Extend Shelf Life of Sweet Pepper (Capsicum annum L)
}

\author{
Aabon W. Yanthan ${ }^{1}$, V.R. Sagar ${ }^{2}$, Ajay Arora ${ }^{3}$ and A.K. Singh ${ }^{4}$ \\ ${ }^{1}$ ICAR Research Complex for NEH region, Nagaland Centre, India \\ ${ }^{2}$ Division of FS\&PHT, ${ }^{3}$ Division of Plant Physiology, IARI, New Delhi, India \\ ${ }^{4}$ Centre for protected cultivation technology, New Delhi, India \\ *Corresponding author
}

A B S T R A C T

Keywords

Sweet pepper,

Salicylic acid,

Derivatives, Shelf

life, Post-harvest

Article Info

Accepted:

10 April 2019

Available Online:

10 May 2019
Three sweet pepper varieties viz. Swarna, California wonder and Oroballe were treated with derivatives of salicylic acid viz. Acetyl salicylic acid (ASA), 5 Sulpho salicylic acid (5 SSA) and Gentisic acid (GA) at $0.5 \mathrm{mM}$ and $1 \mathrm{mM}$ concentrations under ambient condition $\left(20 \pm 5^{\circ} \mathrm{C}\right)$ and analyzed for their change in physical and biochemical profile at 3 days interval for 9 days. Fruits treated with $1 \mathrm{mM}$ acetyl salicylic acid and gentisic acid significantly delayed the senescence process by delaying the changes of weight, and firmness. Application of salicylic derivatives also lead to retention of total soluble solids, total phenolics, antioxidants and inhibited enzyme activities such as PME at the end of storage. Thus the derivatives of salicylic acid may be effective in delaying the process of deterioration, maintenance of quality while extending the shelf life of sweet peppers when stored in ambient condition.

\section{Introduction}

Sweet Pepper (Capsicum annum L.) belonging to solanaceae family is a variety of pepper without pungency. It is popular throughout the world for its colourful appearance and flavor. It is also an excellent source of antioxidants, vitamins and minerals which serves as an ideal food to combat against various diseases (Navarro et al., 2006). Also an important cash crop in India, it is popular in every Indian culinary dish. However, there are many postharvest problems associated with this crop. The major post harvest problem is excessive softening and shrinkage leading to development of pathological disorders which severely reduce the quality and acceptability of the fruits by the consumers. Rapid deterioration in quality during handling and storage leads to huge post harvest losses (Nyanjage et al., 2005). Chilling injury is also a major postharvest problem for pepper. Lack of proper postharvest management represents the major loss of large quantity of the fresh produce leading to rapid deterioration of quality. Compared with other horticultural products, the pepper genus is very susceptible to water 
loss during storage because it is a hollow fruit, and thus has limited ability to hold large volumes of water for long periods (Kissinger et al., 2005). Weight loss of fruits and vegetable reduces fruit firmness, glossiness, and shelf life resulting in loss of quality and hence low income generation (Diaz-Perez, 2007). Efforts toward maintenance of quality throughout the distribution chain and extending the shelf life of sweet pepper would enhance availability of produce in the market over an extended period, thereby, fulfilling the needs of growers, processors and consumers.

Nowadays, developing safe and reliable management strategies to control postharvest losses becomes imperative. Shelf life of sweet pepper can be extended by various postharvest treatments applied to them. One of the effective chemicals to enhance shelf life of fruits and vegetables is Salicylic acid (SA), a plant hormone, which has been reported to regulate a number of processes in plants such as interference in the biosynthesis and/or action of ethylene and inhibit ethylene production (Srivastava and Dwivedi, 2000). $\mathrm{SA}$ is an endogenous signal molecule, playing a role in regulating stress responses and plant developmental processes including heat production or thermogenesis, photosynthesis, stomatal closures, transpiration, ion uptake and transport, disease resistance, seed germination, sex polarization, crop yield and glycolysis (Klessig and Malamy, 1994). SA has been shown to induce expression of AOX and ROS scavenging genes thus increase the antioxidant capacity of the cells (Asghari and Aghdam, 2010). There are various derivatives of salicylic acid such as acetyl salicylic acid, 5 sulpho salicylic acid, gentisic acid etc. Current research on extending quality and shelf life of sweet pepper includes application of methyl salicylate and methyl jasmonate vapors which effectively reduced the incidence of chilling injury and extended the shelf life of sweet pepper (Fung et al., 2004). $\mathrm{SA}$ and $\mathrm{CaCl}_{2}$ treatments assist in delaying the softening process, enhancing the keeping quality while retaining the nutritional quality of sweet peppers when stored at $25^{\circ} \mathrm{C}$ and 10 ${ }^{\circ} \mathrm{C}$ (Rao et al., 2011). Barman and Asrey (2014) observed SA @ $2.0 \mathrm{mM}$ exhibited lower PLW (15.5\%) in comparison to the untreated mango fruits $(17.63 \%)$ at the end of the storage. Plums treated with postharvest SA application @ $1.5 \mathrm{mM}$ significantly delayed and lowered the respiration rate peaks during storage at $1^{\circ} \mathrm{C}$ for 60 days (Luo et al., 2011).

Current information on post-harvest management of sweet pepper using various derivatives of salicylic acid is scanty in spite of its commercial importance. Therefore, it would be useful to investigate the effect of salicylic acid and its derivatives in extending the shelf life of sweet pepper. Thus, the objective of the study was to assess the effect of various derivatives of salicylic acid in three different sweet pepper varieties stored at ambient condition $\left(20 \pm 5^{\circ} \mathrm{C}\right)$.

\section{Materials and Methods}

\section{General material}

Three sweet pepper varieties were procured from Centre for protected cultivation technology (CPCT), New Delhi. Harvesting was done according to their commercial maturity in which Swarna cv. was usually green, California wonder cv. was Red and Oroballe cv. was Yellow respectively. Harvesting was done in the early morning hours. The fruits were transported to the division of food science and post harvest technology at Indian Agricultural Research Institute, New Delhi. Healthy, uniform-sized fruits were sorted out and the fruits were treated with a solution of sodium hypochlorite (100 ppm) followed by dipping in solution of 
Salicylic acid derivatives viz. Acetyl salicylic acid, 5 Sulpho salicylic acid and Gentisic acid at $0.5 \mathrm{mM}$ and $1 \mathrm{mM}$ concentrations for 10 minutes. Fruits dipped in distilled water were treated as control. They were air dried and subsequently stored in a protective shelf under ambient condition at $20 \pm 5^{\circ} \mathrm{C}$ and 80 $90 \% \mathrm{RH}$. In no way did the time gap between harvest and final storage exceed 24 hours. The fruits were evaluated for their following quality attributes at $0,3,6$ and 9 days interval. The experiment consisted of three replications.

\section{Physiological loss in weight (PLW)}

Sweet peppers were weighed at the beginning of storage and at the end of each storage interval. The total weight loss was calculated in difference between initial and final weight of the fruit and calculated on percentage basis as described by method of AOAC (2000).

\section{Fruit firmness}

Fruit firmness was determined using a texture analyzer (model: TA+Di, Stable micro systems, UK) using compression test. Hardness was defined as maximum force (kgf) during the compression, which was expressed in Newtons $(\mathrm{N})$.

\section{TSS}

The total soluble solids of samples were estimated using FISHER Hand Refractometer (0 - 50). The results were expressed as degree brix ( $\left.{ }^{\circ} \mathrm{Brix}\right)$ at $20^{\circ} \mathrm{C}$ refractrometer as described in AOAC (2000).

\section{Total phenolic content}

The total phenolic content was determined following Singleton and Rossi method (1965) with some modifications. Five gram of fruit sample was crushed in $10 \mathrm{ml}$ of $80 \%$ ethanol followed by centrifugation. The homogenate was centrifuged at $10,000 \mathrm{rpm}$ for $20 \mathrm{~min}$ at $4^{\circ} \mathrm{C}$ and supernatant was used for assay of total phenols. $0.5 \mathrm{ml}$ of the sample was added to $2.5 \mathrm{ml}$ of $0.2 \mathrm{~N}$ Folin-Ciocalteau (FC) reagents and placed for $5 \mathrm{~min} .2 \mathrm{ml}$ of $20 \%$ of $\mathrm{Na}_{2} \mathrm{CO}_{3}$ was then added and the total volume made up to $25 \mathrm{ml}$ using $80 \%$ ethanol. The above solution was then kept for incubation in boiling water bath for $15 \mathrm{~min}$ till it became blue-black. Absorbance was measured at 760 nm using $1 \mathrm{~cm}$ cuvette in a Perkin-Elmer UVVIS Lambda 25 Spectrophotometer. Gallic acid $(0$ - $800 \mathrm{mg} / \mathrm{L})$ was used to produce standard calibration curve. The total phenol content was expressed in $\mu \mathrm{g}$ of Gallic acid equivalents (GAE) / g of extract.

\section{Total antioxidant capacity}

Antioxidant capacity was determined by following CUPRAC method, which was standardized by Apak et al., (2004). Cupric reducing antioxidant capacity measures the copper (II) or cupric ion reducing ability of polyphenols. It makes use of the copper (II)neocuproine $[\mathrm{Cu}$ (II)-Nc] reagent as the chromogenic oxidizing agent. The method comprises mixing of the antioxidant solution with a copper (II) chloride solution, a neocuproine alcoholic solution, and an ammonium aqueous buffer at $\mathrm{pH} 7.0$ and subsequent measurement of the developed absorbance at $450 \mathrm{~nm}$ after $30 \mathrm{~min}$. The standard calibration curve of each antioxidant compound was constructed and the antioxidant activity was expressed as $\mu \mathrm{mol}$ trolox equiv. $\mathrm{g}^{-1}$.

\section{Pectin methyl esterase (PME) activity}

Pectin methyl esterase (PME) activity was measured following the method of Hagerman and Austin (1986) with minor modifications. The method is based on the colour change of a $\mathrm{pH}$ indicator during the PME catalysed 
reaction. The acid produced by PME action lowers the $\mathrm{pH}$ of the medium and thereby cause protonation of the indicator dye to produce a change in absorbance at $620 \mathrm{~nm}$. The change in absorbance is continuously monitored spectrophotometrically and the initial rate of reaction is determined. $5 \mathrm{~g}$ of fruit pulp was homogenized in $15 \mathrm{ml}$ of cold $\left(4^{\circ} \mathrm{C}\right) 8.8 \% \mathrm{NaCl}$ using pestle and mortar. The homogenate was then centrifuged at $15,000 \times$ $\mathrm{g}$ for $15 \mathrm{~min}$. The supernatant was collected and its $\mathrm{pH}$ was adjusted to 7.5 with $\mathrm{NaOH}$, after which it was used for enzyme assay. In a cuvette $2.0 \mathrm{ml}$ of pectin was mixed with 0.15 $\mathrm{ml}$ of bromothymol blue and $0.83 \mathrm{ml}$ of water. The absorbance of the mixture was read against water as blank at $620 \mathrm{~nm}$. A constant value of $\mathrm{A}_{620}$ at this stage indicate that there was no non-enzymatic hydrolysis occurring. The reaction was started by adding $20 \mu \mathrm{l}$ of enzyme solution and the rate of decrease in $\mathrm{A}_{620}$ was recorded. Graph was plotted (O.D. vs. time) and rate of reaction was determined from the linear portion of the graph. PME activity was expressed as $(0.328$

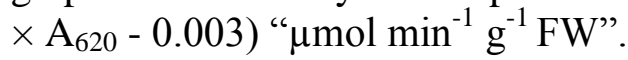

\section{Statistical analysis}

Data analysis was carried out with three replications using ANOVA techniques in factorial CRD (Panse, and Sukhatme, 1984)

\section{Results and Discussion}

\section{Physiological loss in weight (PLW)}

There was overall increase in the rate of physiological weight loss observed throughout the storage period (Table 1). Among the three varieties Swarna recorded least increase in the PLW (12.28\%) at the end of $9^{\text {th }}$ day storage period when treated with $1 \mathrm{mM}$ acetyl salicylic acid. $1 \mathrm{mM}$ acetyl salicylic acid recorded low level of PLW in Swarna $(7.10 \%)$ and oroballe $(16.11 \%)$ where as in California Wonder, gentisic acid (1 $\mathrm{mM})$ treated fruits recorded least PLW $(15.09 \%)$. On $9^{\text {th }}$ day of storage period, highest PLW was recorded in control samples in all the three varieties. Lower rate of PLW in ACA treated fruits could be due to maintenance of cell wall integrity, low respiration rate and reduced transpiration rate by means of inducing stomatal closure (Zheng and Zhang, 2004; Shafiee et al., 2010). Storage at unfavorable condition could also lead to tissue disruption resulting in higher cellular respiration which allowed rapid loss of water from the fruit (Barman et al., 2011). Therefore salicylic acid maintained higher fruit firmness by maintaining cell membrane integrity which ultimately leads to less water loss and less shriveling.

\section{Fruit firmness}

The cursory glance of table 2 indicated that, firmness of sweet pepper during storage decreased rapidly with the advancement of storage period in all the treatments. A marked decrease in fruit firmness was observed in control fruits with $40 \%$ reduction in the firmness in california wonder variety. Higher firmness was recorded in fruits treated with salicylic acid derivatives with highest firmness $(22.95 \mathrm{~N})$ observed in Swarna variety treated with $1 \mathrm{mM}$ acetyl salicylic acid. No significant differences in the firmness were observed among the three varieties. At the end of $9^{\text {th }}$ day of storage, highest firmness $(22.95 \mathrm{~N})$ was found in 1 $\mathrm{mM}$ acetyl salicylic acid followed by California wonder with $21.08 \mathrm{~N}$ while oroballe variety recorded least firmness $(17.48 \mathrm{~N})$ in control fruits. Maintaining fruit firmness is an important quality parameter which influences consumer acceptability. Application of $1 \mathrm{mM}$ concentration of acetyl salicylic acid maintained best level of fruit firmness during 9 days of storage. Softening of fruits and activity of cell wall degrading 
enzymes such as PG and PME are in close association as stated by Ruoyi et al., (2005). Better firmness of fruit observed in salicylic acid treated sweet pepper could be due to influence of salicylic acid in lowering the activity of cell wall degrading enzymes such as PME and PG. Ethylene induce high activity of such softening enzymes according to Khan et al., (2007). Ethylene biosynthesis resulted in increased level of cell wall degrading enzymes according to Zhang et al., (2003). Therefore higher level of firmness in salicylic acid treated sweet pepper could be attributed to reduction of ethylene biosynthesis by salicylic acid which consequently lowered the activity of cell wall degrading enzymes and thereby helped in retaining the firmness.

\section{TSS}

The result on the effect of different treatments on TSS of sweet pepper kept at ambient temperature showed that there was a marked increase in TSS with the advancement of storage period (Table 3). From the presented data it was evident that, irrespective of treatments there was increase in TSS with progression of storage period. Among the treatments, actyl salicylic acid $(1 \mathrm{mM})$ showed best result by least increase in TSS in all the three varieties. No significant difference was observed among the varieties. Control showed the highest increase in the percentage of TSS for all the three varieties with highest increase of TSS upto $47.48 \%$ in oroballe variety. Increase in TSS was recorded in all the experiments during the 9 days of storage period. This phenomenon is attributed to the hydrolysis of starch into sugars like glucose, fructose, and sucrose. The increase in TSS was recorded significantly higher $(\mathrm{p}<0.05)$ in control samples compared to treatments. The present study revealed that salicylic acid treatment lowers the rate of increase in TSS value implying that salicylic acid can slow down the senescence process in sweet pepper. The rate of reduction in the percentage of TSS as compared to untreated fruits could be due to decrease in respiration rate and metabolic activity thereby retarding the overall ripening process. With slower respiration rate, the synthesis and utilization of metabolites and conversion of carbohydrates to sugars also slowed down which in turn lower the TSS according to Ali et al., (2011)

\section{Total phenolic content}

The data presented in Table 4 revealed that all the treatments had significant influence on total phenolics content of sweet pepper during storage. Irrespective of the different treatments, phenolics content decreased progressively with the advancement of storage period. In general, total phenolics content was significantly lower in untreated control fruits. In swarna variety, Gentisic acid (1 $\mathrm{mM})$ retained significantly higher total phenol content over the control during entire storage period of 9 days where as in California Wonder and Oroballe varieties, 1 $\mathrm{mM}$ acetyl salicylic acid retained higher total phenols over the control samples. Phenolics are important dietary compounds related to the antioxidant activity of sweet pepper. The content of total phenols gradually decreased with progress in storage period.

However, derivatives of salicylic acid treatment resulted in retention of higher total phenol content in sweet pepper compared to control during the entire storage period of 9 days. Both gentisic acid ( $1 \mathrm{mM})$ and acetyl salicylic acid $(1 \mathrm{mM})$ treatments recorded higher level of total phenols at the end of storage period. This could be due to decreased activity of polyphenol oxidase enzyme and high activity of phenylalanine ammonia lyase enzymes. Polyphenol oxidase enzyme is responsible for the oxidation of phenols to 
quinones and forms brown polymers by tannin condensation (Zhu et al., 2009).

\section{Total antioxidant capacity}

The effect of salicylic acid and its derivatives on antioxidant activity of sweet pepper during 9 days of storage is depicted in Table 5. Antioxidant capacity was found to be significantly affected by different salicylic acid treatments, storage days and their interaction. Irrespective of treatments, the antioxidant capacity decreased in all the treatments including control. At end of storage, among the varieties, least reduction of antioxidant capacity (15.50\%) was recorded in Swarna variety treated with $1 \mathrm{mM}$ acetyl salicylic acid followed by $1 \mathrm{mM}$ Gentisic acid in California Wonder variety (21.46\% reduction), while the highest reduction $(49.92 \%)$ was observed in control fruits of Oroballe variety. Reduction in antioxidant activity was observed in all the varieties irrespective of treatments during 9 days of storage. Among the different treatments, Swarna variety treated with $1 \mathrm{mM}$ acetyl salicylic acid recorded highest antioxidant capacity followed $1 \mathrm{mM}$ Gentisic acid in California Wonder variety. Sweet pepper has high concentration of biologically active compounds such as phenolics, ascorbic acid, vitamins, chlorophylls and other phytochemicals as reported by Marín et al., (2004). Higher antioxidant capacity exhibited in salicylic acid derivatives treated sweet pepper could be due to higher content of antioxidant compounds. The findings were in agreement with Razavi et al., (2014), who also reported that SA treatment maintained higher antioxidant capacity in peach. Barman and Asrey (2014) also reported similar trend in mango. Decrease in antioxidant capacity during storage period can be attributed to oxidation of phenolics compounds to other compounds and reduction in ascorbic acid which is an antioxidant.

\section{Pectin methyl esterase (PME) activity}

The effect of different salicylic acid treatments on PME activity of sweet pepper is presented in Table 6.

Table.1 Effect of Salicylic acid and its derivatives on PLW (\%) of sweet pepper during storage at ambient condition $\left(20 \pm 5^{\circ} \mathrm{C}\right)$

\begin{tabular}{|c|c|c|c|c|c|c|c|c|c|c|c|c|}
\hline \multirow{3}{*}{$\begin{array}{l}\text { Variety (A) } \\
\begin{array}{l}\text { Treatment } \\
\text { (B) }\end{array}\end{array}$} & \multicolumn{12}{|c|}{ Storage Days (C) } \\
\hline & \multicolumn{4}{|c|}{ Swarna (Green) } & \multicolumn{4}{|c|}{$\begin{array}{c}\text { California Wonder } \\
\text { (Red) }\end{array}$} & \multicolumn{4}{|c|}{ Oroballe (Yellow) } \\
\hline & $\mathbf{0}$ & 3 & 6 & 9 & $\mathbf{0}$ & 3 & 6 & 9 & $\mathbf{0}$ & 3 & 6 & 9 \\
\hline Control & 0 & 4.78 & 8.05 & 15.92 & 0 & 5.20 & 8.53 & 18.32 & 0 & 5.42 & 9.04 & 19.36 \\
\hline T1 & 0 & 4.57 & 7.47 & 14.91 & 0 & 5.19 & 7.42 & 17.57 & 0 & 4.78 & 7.82 & 17.57 \\
\hline $\mathbf{T 2}$ & 0 & 4.15 & 7.10 & 12.28 & 0 & 4.76 & 7.29 & 16.19 & 0 & 4.74 & 7.55 & 16.11 \\
\hline T3 & 0 & 4.65 & 7.66 & 15.42 & 0 & 5.18 & 8.29 & 18.23 & 0 & 5.16 & 8.18 & 18.57 \\
\hline T4 & 0 & 4.34 & 7.73 & 14.49 & 0 & 4.91 & 8.19 & 18.08 & 0 & 5.11 & 8.37 & 18.60 \\
\hline T5 & 0 & 4.41 & 7.51 & 13.18 & 0 & 4.65 & 7.18 & 15.09 & 0 & 4.80 & 7.82 & 16.67 \\
\hline T6 & 0 & 4.25 & 7.48 & 12.46 & 0 & 4.67 & 7.34 & 16.24 & 0 & 4.59 & 7.74 & 17.24 \\
\hline
\end{tabular}

CD@ $5 \%$

$\mathbf{A}=0.191 ; \mathbf{B}=0.292 ; \mathbf{C}=0.221 ; \mathbf{A} \times \mathbf{x}=\mathrm{NS} ; \mathbf{A} \times \mathbf{~ C}=0.382 ; \mathbf{B} \times \mathbf{~ C}=0.584 ; \mathbf{A} \times \mathbf{~} \mathbf{B} \times \mathbf{C}=\mathrm{NS}$

T1: Acetyl Salicylic Acid (0.5 mM) ; T2: Acetyl Salicylic Acid (1.0 mM); T3: 5 Sulpho Salicylic Acid (0.5 mM); T4: 5 Sulpho Salicylic Acid (1 mM); T5: Gentisic Acid ( $0.5 \mathrm{mM})$;T6: Gentisic Acid (1 mM); Control: Distilled water

Table. 2 Effect of Salicylic acid and its derivatives on firmness (N) of sweet pepper during 
storage at ambient condition $\left(20 \pm 5^{\circ} \mathrm{C}\right)$

\begin{tabular}{|c|c|c|c|c|c|c|c|c|c|c|c|c|}
\hline Variety (A) & \multicolumn{9}{|c|}{ Storage Days (C) } \\
\cline { 2 - 16 } & \multicolumn{3}{|c|}{ Swarna (Green) } & \multicolumn{10}{c|}{ California Wonder (Red) } & \multicolumn{3}{c|}{ Oroballe (Yellow) } \\
\hline $\begin{array}{c}\text { Treatment } \\
\text { (B) }\end{array}$ & $\mathbf{0}$ & $\mathbf{3}$ & $\mathbf{6}$ & $\mathbf{9}$ & $\mathbf{0}$ & $\mathbf{3}$ & $\mathbf{6}$ & $\mathbf{9}$ & $\mathbf{0}$ & $\mathbf{3}$ & $\mathbf{6}$ & $\mathbf{9}$ \\
\hline Control & 31.59 & 30.85 & 25.54 & 19.57 & 29.84 & 25.42 & 21.95 & 17.79 & 28.49 & 24.34 & 21.37 & 17.48 \\
\hline T1 & 31.59 & 30.89 & 27.6 & 21.39 & 29.84 & 26.36 & 23.78 & 19.68 & 28.49 & 26.54 & 24.03 & 19.94 \\
\hline T2 & 31.59 & 30.92 & 29.19 & 22.95 & 29.84 & 27.69 & 24.36 & 20.61 & 28.49 & 27.36 & 25.78 & 20.41 \\
\hline T3 & 31.59 & 30.52 & 26.88 & 20.21 & 29.84 & 25.69 & 23.06 & 19.85 & 28.49 & 25.04 & 23.15 & 18.99 \\
\hline T4 & 31.59 & 30.57 & 26.89 & 20.65 & 29.84 & 25.41 & 23.08 & 19.91 & 28.49 & 24.69 & 22.00 & 18.67 \\
\hline T5 & 31.59 & 30.92 & 28.30 & 21.98 & 29.84 & 26.38 & 23.53 & 19.75 & 28.49 & 25.26 & 23.13 & 18.41 \\
\hline T6 & 31.59 & 31.15 & 29.06 & 22.32 & 29.84 & 27.05 & 24.81 & 21.08 & 28.49 & 26.69 & 23.20 & 20.68 \\
\hline
\end{tabular}

CD @ 5\%

$\mathbf{A}=0.191 ; \mathbf{B}=0.292 ; \mathbf{C}=0.221 ; \mathbf{A} \times \mathbf{B}=\mathrm{NS} ; \mathbf{A} \times \mathbf{C}=0.382 ; \mathbf{B} \times \mathbf{C}=0.584 ; \mathbf{A} \times \mathbf{B} \times \mathbf{C}=\mathrm{NS}$

T1: Acetyl Salicylic Acid (0.5 mM) ; T2: Acetyl Salicylic Acid (1.0 mM); T3: 5 Sulpho Salicylic Acid (0.5 mM);

T4: 5 Sulpho Salicylic Acid (1 mM); T5: Gentisic Acid (0.5 mM);T6: Gentisic Acid (1 mM); Control: Distilled water

Table.3 Effect of Salicylic acid and its derivatives on TSS $\left({ }^{\circ}\right.$ Brix $)$ of Sweet Pepper during storage at ambient condition $\left(20 \pm 5^{\circ} \mathrm{C}\right)$

\begin{tabular}{|c|c|c|c|c|c|c|c|c|c|c|c|c|}
\hline $\begin{array}{c}\text { Variety } \\
\text { (A) }\end{array}$ & \multicolumn{9}{|c|}{ Storage Days (C) } \\
\cline { 2 - 17 } & \multicolumn{3}{|c|}{ Swarna (Green) } & \multicolumn{10}{c|}{ California Wonder (Red) } & \multicolumn{3}{c|}{ Oroballe (Yellow) } \\
\hline $\begin{array}{c}\text { Treatment } \\
\text { (B) }\end{array}$ & $\mathbf{0}$ & $\mathbf{3}$ & $\mathbf{6}$ & $\mathbf{9}$ & $\mathbf{0}$ & $\mathbf{3}$ & $\mathbf{6}$ & $\mathbf{9}$ & $\mathbf{0}$ & $\mathbf{3}$ & $\mathbf{6}$ & $\mathbf{9}$ \\
\hline Control & 3.30 & 3.83 & 4.96 & 4.90 & 5.63 & 5.83 & 6.36 & 8.30 & 5.96 & 6.06 & 7.23 & 8.79 \\
\hline T1 & 3.30 & 3.36 & 3.96 & 4.56 & 5.63 & 5.76 & 6.00 & 7.11 & 5.96 & 5.80 & 6.48 & 7.83 \\
\hline T2 & 3.30 & 3.4 & 3.82 & 3.98 & 5.63 & 5.70 & 5.90 & 6.83 & 5.96 & 5.66 & 6.13 & 7.35 \\
\hline T3 & 3.30 & 3.56 & 4.10 & 4.59 & 5.63 & 5.78 & 6.47 & 7.38 & 5.96 & 5.96 & 6.80 & 7.96 \\
\hline T4 & 3.30 & 3.50 & 4.23 & 4.41 & 5.63 & 5.91 & 6.68 & 7.43 & 5.96 & 5.99 & 6.97 & 8.17 \\
\hline T5 & 3.30 & 3.46 & 3.85 & 4.21 & 5.63 & 5.73 & 6.13 & 7.00 & 5.96 & 5.83 & 6.30 & 7.69 \\
\hline T6 & 3.30 & 3.40 & 3.93 & 4.33 & 5.63 & 5.83 & 6.30 & 7.28 & 5.96 & 5.61 & 6.25 & 7.53 \\
\hline
\end{tabular}

CD @ $5 \%$

$\mathbf{A}=\mathrm{NS} ; \mathbf{B}=0.136 ; \mathbf{C}=0.103 ; \mathbf{A} \times \mathbf{B}=\mathrm{NS} ; \mathbf{A} \times \mathbf{C}=0.178 ; \mathbf{B} \times \mathbf{C}=0.273 ; \mathbf{A} \times \mathbf{B} \times \mathbf{C}=\mathrm{NS}$

T1: Acetyl Salicylic Acid (0.5 mM) ; T2: Acetyl Salicylic Acid (1.0 mM); T3: 5 Sulpho Salicylic Acid (0.5 mM);

T4: 5 Sulpho Salicylic Acid (1 mM); T5: Gentisic Acid (0.5 mM);T6: Gentisic Acid (1 mM); Control: Distilled water

Table.4 Effect of Salicylic acid and its derivatives on total phenols (mg GAE/g) of sweet pepper 
during storage at ambient condition $\left(20 \pm 5^{\circ} \mathrm{C}\right)$

\begin{tabular}{|c|c|c|c|c|c|c|c|c|c|c|c|c|}
\hline \multirow{3}{*}{\begin{tabular}{|c|} 
Variety \\
(A) \\
$\begin{array}{c}\text { Treatment } \\
\text { (B) }\end{array}$
\end{tabular}} & \multicolumn{12}{|c|}{ Storage Days (C) } \\
\hline & \multicolumn{4}{|c|}{ Swarna (Green) } & \multicolumn{4}{|c|}{ California Wonder (Red) } & \multicolumn{4}{|c|}{ Oroballe (Yellow) } \\
\hline & $\mathbf{0}$ & 3 & 6 & 9 & $\mathbf{0}$ & 3 & 6 & 9 & $\mathbf{0}$ & 3 & $\mathbf{6}$ & 9 \\
\hline Control & 14.93 & 12.54 & 10.94 & 6.87 & 12.65 & 10.44 & 8.53 & 5.77 & 10.83 & 9.59 & 7.01 & 4.91 \\
\hline T1 & 14.93 & 14.15 & 12.08 & 9.05 & 12.65 & 11.70 & 10.15 & 7.25 & 10.83 & 10.45 & 8.29 & 6.24 \\
\hline $\mathbf{T 2}$ & 14.93 & 14.06 & 11.97 & 9.25 & 12.65 & 10.93 & 10.73 & 8.18 & 10.83 & 10.51 & 8.82 & 6.93 \\
\hline T3 & 14.93 & 12.91 & 9.77 & 7.55 & 12.65 & 10.77 & 8.92 & 6.94 & 10.83 & 10.34 & 7.97 & 5.13 \\
\hline T4 & 14.93 & 13.41 & 9.69 & 7.61 & 12.65 & 10.67 & 8.41 & 6.69 & 10.83 & 9.71 & 7.78 & 5.11 \\
\hline T5 & 14.93 & 14.43 & 12.50 & 9.66 & 12.65 & 11.08 & 9.26 & 7.26 & 10.83 & 10.56 & 8.58 & 6.48 \\
\hline T6 & 14.93 & 14.59 & 12.74 & 10.00 & 12.65 & 11.59 & 10.93 & 7.95 & 10.83 & 10.60 & 8.12 & 6.16 \\
\hline
\end{tabular}

CD@ $5 \%$

$\mathbf{A}=0.191 ; \mathbf{B}=0.292 ; \mathbf{C}=0.208 ; \mathbf{A} \times \mathbf{B}=0.360 ; \mathbf{A} \times \mathbf{C}=0.272 ; \mathbf{B} \times \mathbf{~ C}=0.416 ; \mathbf{A} \times \mathbf{B} \times \mathbf{C}=0.720$

T1: Acetyl Salicylic Acid (0.5 mM) ; T2: Acetyl Salicylic Acid (1.0 mM); T3: 5 Sulpho Salicylic Acid (0.5 mM);

T4: 5 Sulpho Salicylic Acid (1 mM); T5: Gentisic Acid (0.5 mM);T6: Gentisic Acid (1 mM); Control: Distilled water

Table.5 Effect of Salicylic acid and its derivatives on total antioxidants (mMTrolox/g) of sweet pepper during storage at ambient condition $\left(20 \pm 5^{\circ} \mathrm{C}\right)$

\begin{tabular}{|c|c|c|c|c|c|c|c|c|c|c|c|c|}
\hline \multirow{3}{*}{$\begin{array}{c}\text { Variety } \\
\text { (A) } \\
\text { Treatment } \\
\text { (B) }\end{array}$} & \multicolumn{12}{|c|}{ Storage Days (C) } \\
\hline & \multicolumn{4}{|c|}{ Swarna (Green) } & \multicolumn{4}{|c|}{ California Wonder (Red) } & \multicolumn{4}{|c|}{ Oroballe (Yellow) } \\
\hline & $\mathbf{0}$ & 3 & 6 & 9 & $\mathbf{0}$ & 3 & 6 & 9 & $\mathbf{0}$ & 3 & 6 & 9 \\
\hline Control & 23.99 & & 17.9 & 16.4 & 46.55 & & 34.0 & 28.3 & 37.86 & 30. & & \\
\hline T1 & 23.99 & 20.97 & 19.77 & 17.43 & 46.55 & 44. & 40.23 & 35.07 & 37.86 & 34.44 & 29.47 & 26.58 \\
\hline $\mathbf{T 2}$ & 23.99 & 22.46 & 21.15 & 20.27 & 46.55 & 41. & 37.21 & 31.41 & 37.86 & 31.22 & 27.26 & 23.77 \\
\hline T3 & 23.99 & 21.90 & 20.36 & 18.08 & 46.55 & 41.03 & 36.92 & 31.20 & 37.86 & 31.92 & 27.99 & 23.36 \\
\hline T4 & 23.99 & 22.85 & 20.59 & 18.50 & 46.55 & 40.41 & 36.22 & 31.30 & 37.86 & 30.52 & 28.53 & 20.16 \\
\hline T5 & 23.99 & 21.48 & 20.81 & 18.59 & 46.55 & 41.64 & 38.39 & 32.41 & 37.86 & 31.29 & 27.01 & 20.51 \\
\hline T6 & 23.99 & 22.74 & 20.46 & 19.08 & 46.55 & 45.30 & 41.41 & 36.56 & 37.86 & 35.19 & 30.46 & 26.86 \\
\hline
\end{tabular}

CD@ $9 \%$

$\mathbf{A}=0.771 ; \mathbf{B}=1.178 ; \mathbf{C}=0.890 ; \mathbf{A} \times \mathbf{~ B}=\mathrm{NS} ; \mathbf{A} \times \mathbf{~ C}=0.154 ; \mathbf{B} \times \mathbf{C}=2.355 ; \mathbf{A} \times \mathbf{B} \times \mathbf{C}=\mathrm{NS}$

T1: Acetyl Salicylic Acid (0.5 mM) ; T2: Acetyl Salicylic Acid (1.0 mM); T3: 5 Sulpho Salicylic Acid (0.5 mM);

T4: 5 Sulpho Salicylic Acid (1 mM); T5: Gentisic Acid ( $0.5 \mathrm{mM})$;T6: Gentisic Acid (1 mM); Control: Distilled water

Table.6 Effect of salicylic acid and its derivatives on PME activity (A620 $\mathrm{min}^{-1} \mathrm{mg}^{-1}$ proteins) 
of Sweet Pepper during storage at ambient condition $\left(20 \pm 5^{\circ} \mathrm{C}\right)$

\begin{tabular}{|c|c|c|c|c|c|c|c|c|c|c|c|c|}
\hline \multirow{3}{*}{$\begin{array}{l}\text { Variety (A) } \\
\text { Treatment } \\
\text { (B) }\end{array}$} & \multicolumn{12}{|c|}{ Storage Days (C) } \\
\hline & \multicolumn{4}{|c|}{ Swarna (Green) } & \multicolumn{4}{|c|}{ California Wonder (Red) } & \multicolumn{4}{|c|}{ Oroballe (Yellow) } \\
\hline & $\mathbf{0}$ & 3 & 6 & 9 & $\mathbf{0}$ & 3 & 6 & 9 & $\mathbf{0}$ & 3 & 6 & 9 \\
\hline Control & 0.002 & 0.008 & 0.023 & 0.045 & 0.005 & 0.009 & 0.053 & 0.083 & 0.006 & 0.009 & 0.070 & 0.100 \\
\hline T1 & 0.002 & 0.004 & 0.006 & 0.019 & 0.005 & 0.005 & 0.009 & 0.040 & 0.006 & 0.007 & 0.016 & 0.057 \\
\hline $\mathbf{T} 2$ & & & & 0.010 & & 0.006 & 0.019 & 0.033 & 0.006 & 0.007 & 0.022 & 0.047 \\
\hline T3 & 0.002 & 0.005 & 0.008 & 0.020 & 0.005 & 0.006 & 0.016 & 0.063 & 0.006 & 0.007 & 0.029 & 0.070 \\
\hline T4 & 0.002 & 0.005 & 0.008 & 0.023 & 0.005 & 0.007 & 0.033 & 0.063 & 0.006 & 0.008 & 0.040 & 0.083 \\
\hline T5 & 0.002 & 0.003 & 0.005 & 0.017 & 0.005 & 0.005 & 0.006 & 0.016 & 0.006 & 0.006 & 0.006 & 0.026 \\
\hline T6 & 0.002 & 0.004 & 0.005 & 0.019 & 0.005 & 0.006 & 0.008 & 0.019 & 0.006 & 0.007 & 0.008 & 0.053 \\
\hline
\end{tabular}

CD@ $5 \%$

$\mathbf{A}=0.003 ; \mathbf{B}=0.004 ; \mathbf{C}=0.221 ; \mathbf{A} \times \mathbf{B}=0.007 \mathrm{~S} ; \mathbf{A} \times \mathbf{C}=0.006 ; \mathbf{B} \times \mathbf{C}=0.008 ; \mathbf{A} \times \mathbf{B} \times \mathbf{C}=0.005$

T1: Acetyl Salicylic Acid (0.5 mM) ; T2: Acetyl Salicylic Acid (1.0 mM); T3: 5 Sulpho Salicylic Acid (0.5 mM);

T4: 5 Sulpho Salicylic Acid (1 mM); T5: Gentisic Acid ( $0.5 \mathrm{mM})$;T6: Gentisic Acid (1 mM); Control: Distilled water

Irrespective of treatments, PME activity showed increasing trend till the end of 9 days of storage period in all varieties the varieties studied. However, fruits treated with acetyl acid and gentisic acid showed significantly lower PME activity over control. Among the different treatments, $1 \mathrm{mM}$ ASA treatment recorded lower PME activity in Swarna and California wonder varieties whereas $0.5 \mathrm{mM}$ gentisic acid recorded least PME activity in oroballe variety. Untreated fruits in all three varieties exhibited highest activity of PME during the entire storage period for 9 days. Higher PME activities in untreated fruits could be due to decrease of fruit firmness and disintegration of cellular components by the process of senescence (Gómez-Galindo et al., 2004). Lesser PME activity in salicylic acid derivatives treated sweet pepper treated could also be due to retention of firmness by lowering the activity of cell wall degrading enzymes mainly pectin methyl esterase and polygalacturonase. Research findings were also supported by Barman and Asrey (2014), who reported that salicylic acid treated mango fruit had significantly lower enzymatic activity than control.

Acknowledgement
Authors are indebted to Indian Agricultural Research Institute, New Delhi for providing every facility required while carrying out this work.

\section{References}

A.O.A.C. (2000). Official methods of analysis. 17th ed. Association of Official Analytical Chemists, Gaithersburg, MD.

Ali, A., Muhammad, M.T.M., Sijam, K., Siddiqui, Y. 2011. Effect of chitosan coatings on the physicochemical characteristics of Eksotika II papaya (Carica papaya L.) fruit during cold storage. Food Chem., 124: 620-626.

Apak, R., Guclu, K., Ozyurek, M. and Karademir, S.E. 2004. Novel total antioxidant capacity index for dietary polyphenol and vitamins $\mathrm{C}$ and $\mathrm{E}$, using their cupric ion reducing capability in the presence of neocuproine, CUPRAC method. J. Agric. Food Chem., 52: 7970-7981.

Asghari, M, and Aghdam, M.S. 2010. Impact of salicylic acid on postharvest physiology of horticultural crops. 
Trends Food Sci. Technol., 2:502-509.

Barman, K., Asrey, R. and Pal, R.K. 2011. Putrescine and carnauba wax pretreatments alleviate chilling injury, enhance shelf life and preserve pomegranate fruit quality during cold storage. Sci. Hortic., 130: 795-800.

Barman, k., Asrey, R., Pal, R.K. Jha, S.K. and Bhatia, K. 2014. Post-harvest nitric oxide treatment reduces chilling injury and enhances the shelf-life of mango (Mangifera indica L.) fruit during lowtemperature storage. J. Hortic. Sci. Biotech., 89 (3): 253-260.

Barman. K. and Asrey, R. 2014. Salicylic acid pre-treatment alleviates chilling injury, preserves bioactive compounds and enhances shelf life of mango fruit during cold storage. J. Sci. Ind. Res.., 73:713-718.

Díaz-Pérez, J.C., Muy-Rangel, M.D., Mascorro, A.G., 2007. Fruit size and stage of ripeness affect postharvest water loss in bell pepper fruit (Capsicum annuum L.). J. Sci. Food Agric. 87, 68-73.

Fung, R.W.M., Wang, C.Y., Smith, D.L., Gross, K.C., Tian, M., 2004. MeSA and MeJA increase steady-state transcript levels of alternative oxidase and resistance against chilling injury in sweet peppers (Capsicum annuum L.). Plant Science 166, 711-719.

Gómez-Galindo, F., Herppich, W., Gekas, V. and Sjöholm, I. 2004. Factors affecting quality and postharvest properties of vegetables: Integration of water relations and metabolism. Crit. Rev. Food Sci. Nutr., 44: 139-154.

Hagerman, A.E. and Austin, P.J. 1986. Continuous spectrophotometry assay for plant pectin methyl esterase. J. agric. Food Chem., 34: 440-444.

Khan, S.A., Singh, Z. and Nadeem, A. 2007. Pre-storage putrescine application suppresses ethylene biosynthesis and retards fruit softening during low temperature storage in 'Angelino' plum. Postharvest Biol. Technol., 46: 36-46.

Kissinger, M., Tuvia-Alkalai, S., Shalom, Y., Fallik, E., Elkind, Y., Jenks, M.A., Goodwin, M.S., 2005. Characterization of physiological and biochemical factors associated with postharvest water loss in ripe pepper fruit during storage. J. Am. Soc. Hortic. Sci. 130, 735-741.

Klessig, D.F. and Malamy, J. 1994. The salicylic acid signal in plants. Plant Mol. Biol., 26: 1439-1458.

Luo, Z., Chen, C. and Xie, J. 2011. Effect of salicylic acid treatment on alleviating postharvest chilling injury of 'Qingnai' plum fruit. Postharvest Biol. Technol., 62: 115-120.

Marín, A., Ferreres, F., Tomás-Barberán, F.A., Gil, M.I., 2004. Characterization and quantitation of antioxidant constituents of sweet pepper (Capsicum annuum L.). J. Agric. Food Chem. 52, 3861-3869.

Navarro, J., Flores, P., Garrido, C., Martinez, V., 2006. Changes in the contents of antioxidant compounds in pepper fruits at different ripening stages, as affected by salinity. Food Chemistry 96, 66-73.

Nyanjage, M.O., Nyalala, S.P.O., Illa, A.O., Mugo, B.W., Limbe, A.E., Vulimu, E.M., 2005. Extending post-harvest life of sweet pepper (Capsicum annum L. 'California Wonder') with modified atmosphere packaging and storage temperature. Agric. Trop. Subtrop. 38, 28-34.

Panse, V. G. and Sukhatme, P. V. (1984) Statistical methods for agricultural workers. ICAR, New Delhi.

Rao, T.V.R, Gol N.B., and Shah K.K. 2011. Effect of postharvest treatments and storage temperatures on the quality and shelf life of sweet pepper (Capsicum annum L.). Scientia Horticulturae 132 
$18-26$.

Razavi, R., Hajilou, J., Dehgan, G., Hassani, R.N.B. and Turchi, M. 2014. Enhancement of postharvest quality of peach fruit by salicylic acid treatment. International Journal of Biosciences., 4(1): 177-184.

Ruoyi, K., Zhifang, Y., Zhaoxin, L., 2005. Effect of coating and intermittent warming on enzymes, soluble pectin substances and ascorbic acid of Prunus persica ( $\mathrm{Cv}$. Zhonghuashoutao) during refrigerated storage. Food Res. Int. 38, 331-336.

Shafiee, M., Taghavi, T.S. and Babalar, M. 2010. Addition of salicylic acid to nutrient solution combined with postharvest treatments (hot water, salicylic acid, and calcium dipping) improved postharvest fruit quality of strawberry. Sci Hort., 124: 40-45.

Singleton, V.L. and Rossi, J.A. 1965.
Colorimetry of total phenolics with phosphomolybdic-phosphotungstic acid reagents. Amer. J. Enol. Vitic., 16: 144158.

Srivastava, M.K. and Dwivedi, U.N. 2000. Ripening of banana fruit by salicylic acid. Plant Sci., 158: 87-96.

Zhang, Y., Chen, K.S., Zhang, S.L. and Ferguson, I. 2003. The role of salicylic acid in postharvest ripening of kiwifruit. Postharvest Biol. Technol., 28: 67-74.

Zheng, Y. and Zhang, Q. 2004. Effects of polyamines and salicylic acid on postharvest storage of 'Ponkan' mandarin. Acta Hortic., 632: 317-320.

Zhu, S., Sun, L. and Zhou, J. 2009. Effects of nitric oxide fumigation on phenolic metabolism of postharvest Chinese winter jujube (Zizyphus jujuba Mill. cv. Dongzao) in relation to fruit quality. LWT-Food Sci. Technol., 42: 10091014.

\section{How to cite this article:}

Aabon W. Yanthan, V.R. Sagar, Ajay Arora and Singh, A.K. 2019. Application of Salicylic Acid Derivatives to Extend Shelf Life of Sweet Pepper (Capsicum annum L). Int.J.Curr.Microbiol.App.Sci. 8(05): 644-654. doi: https://doi.org/10.20546/ijcmas.2019.805.075 